\title{
Nextille levelille? - Kohti seuraavan sukupolven sosiaalilääketiedettä
}

\author{
LIINA-KAISA TYNKKYNEN
}

Riikka Lämsä ja Veli-Matti Partanen esittivät tämän lehden kirjoituksessaan ajatusleikin kysymällä, mitkä ovat ne yhteiskunnalliset ja globaalit ilmiöt, epäkohdat ja vahvuudet sekä sosiaalilääketieteen tutkimus- ja vaikuttamistavat, jotka vievät meidät kohti sosiaalilääketiede 2.0:a? Nuoremman tutkijasukupolven edustajana lupasin pohtia aihetta muutaman kappaleen verran Sosiaalilääketieteen yhdistyksen 50-vuotissyntymäpäivän kunniaksi.

Lämsän ja Partasen haastattelemien sosiaalilääketieteen merkittävien vaikuttajien kanssa on helppo olla samaa mieltä siitä, että sosiaalilääketieteen peruspilareita ovat monitieteiden lähestymistapa terveyden ja sairauden kysymyksiin, terveyden ja yhteiskunnallisten ilmiöiden yhteen kietoutuminen kysymyksenasetteluissa sekä pyrkimys terveyden parempaan tasoon, oikeudenmukaisuuteen ja tasa-arvoon. Monelta osin myös haasteet ovat pysyneet samoina. Esimerkiksi terveyden eriarvoisuus sekä terveyden ja sairauden yhteiskunnallisten syiden monimuotoinen suhde ovat edelleen relevantteja sosiaalilääketieteellisen tutkimuksen ja vaikuttamistyön teemoja.

Tulevaisuuden sosiaalilääketieteen toimintaympäristössä on kuitenkin nähtävissä myös muutoksia verrattuna aikaan, jolloin uutta sosiaalilääketiedettä on luotu. Sosiaalilääketieteen voidaankin ajatella elävän jonkinasteista "viidenkympin villitystä”, jonka pyörteissä se, vanhojen haasteiden ohella, hakee uutta identiteettiä ja paikkaa jälkimodernissa yhteiskunnassa.

Yhtäältä uudelleen asemoinnin tarve kumpuaa sosiaalilääketieteen kannalta olennaisten kysymysten kirjon jonkinasteisesta muutoksesta. Lääketieteen läpimurrot mahdollistavat entistä suuremman määrän hoitoja samaan aikaan kun julkisen sektorin resurssit ovat aikaisempaa rajallisemmat. Globaali kehitys, kuten ilmastonmuutos ja antibioottiresistenssin kasvu, haastavat kansallisia palvelujärjestelmiä ja lääketieteen käytäntöjä. Teknologian kehitys tuo mukanaan paljon mahdollisuuksia, mutta herättää paljon myös kysymyksiä terveysriskeistä ja eriarvoisuudesta. Globaalit (terveys)trendit vaikuttavat entistä enemmän ihmisten terveysvalintoihin kansallisten ohjelmien sijaan. Palvelujärjestelmät uudistuvat jatkuvasti ja houkuttavat entistä laajemmin myös kaupallisia intressejä edustavia tahoja. Esimerkiksi näihin ja moniin muihin kysymyksiin ja teemoihin sosiaalilääketieteilijöiden soisi ottavan aktiivisesti kantaa ja kohdistavan tutkimustoimintaansa tulevaisuudessa.

Toisaalta sosiaalilääketieteen uuden roolin hakeminen liittyy tutkimuksen ja koulutuksen kentällä tapahtuneisiin uudistuksiin. Esimerkiksi tutkimusrahoituksen painopisteissä tapahtuneet muutokset, valtion sektoritutkimuslaitosten resurssien leikkaukset ja entistä raaempi kilpailu ulkopuolisesta rahoituksesta ovat muuttaneet toimintaympäristöä, jossa sosiaalilääketieteen tutkijat ja vaikuttajat tulevaisuudessa kasvavat, kouluttautuvat ja työskentelevät. Sosiaalilääketieteen pioneerien väistyessä on edessä sukupolven vaihdos, joka ei välttämättä tapahdu haasteitta. Iso kysymys onkin, miten uusi sosiaalilääketieteen tutkijoiden sukupolvi saadaan niin taidoiltaan kuin volyymiltaan kasvamaan isoihin saappaisiin, jotka alan uranuurtajilta aikanaan jäävät täytettäviksi.

Yksi tärkeä osa näihin saappaisiin astumista on yhteiskunnalliseen keskusteluun ja vaikuttamistyöhön osallistuminen. Samaan aikaan kun toimintaympäristö on muuttunut ja asettanut omat haasteensa, sosiaalilääketieteen tutkimuk- 
sen ja vaikuttamistyön tarve ja kysyntä kasvaa jatkuvasti esimerkiksi terveystiedon määrän jatkuvan lisääntymisen ja pirstaloitumisen sekä sotesektorin rakenteita uudistamisen myötä. Kuluneen 50 vuoden aikana myös tutkimusmenetelmät ja aineistojen saatavuus ovat kehittyneet harppauksin. Tämä mahdollistaa entistä monimutkaisempien ongelmien ratkaisemisen sosiaalilääketieteen tutkimuksen keinoin. Sanottavaa ja vaikutettavaa on siis yllin kyllin!

Tieteen ja tutkimuksen yhteiskunnallinen asema ei kuitenkaan ole, eikä se ole koskaan ollut, vankkumaton. Sen olemme saaneet huomata esimerkiksi korkean tason poliitikkojen ulostuloista (1), loppuvuodesta 2017 puhjenneesta hopeavesikohusta (2), rokotuskriittisyydestä tai muista antimedikalisaatiota kuvaavista ilmiöistä (3) sekä yleisestä tieteenedustajien kyseenalaistamisessa terveyteen liittyvissä kysymyksissä (esim. 4). Sosiaalisen median ja tietotulvan maailmassa terveyden asiantuntijuuden spektri onkin laajentunut merkittävästi. Netissä tieto liikkuu vapaasti ja portinvartijuus, joka tutkijoilla ja medialla on aikaisemmin ollut tieteellisen tiedon suhteen, on ainakin joiltain osin murtumassa. (5.) Sosiaalilääketieteilijöiden rinnalle on terveyskysymyksissä tullut jos jonkinlaista personal traineria, elämäntapabloggaria ja biohakkeria, joilla on valtavasti valtaa vaikuttaa ihmisten päätöksiin. Terveysvaikuttajien toimintakenttä on koko maailma ja sosiaalisen median kautta terveyden ja elämäntapojen muoti-ilmiöt leviävät Los Angelesista Lappeenrantaan.

Sosiaalilääketieteilijöiden on entistä tarkemmalla korvalla kuunneltava kansalaisia ja pyrittävä ymmärtämään niitä taustoja, joita muun muassa edellä mainittujen esimerkkien taustoilla piilee. Jotta voisimme päästä seuraavalle tasolle sosiaalilääketieteellisessä tutkimus- ja vaikuttamistyössä on tutkijoiden ja vaikuttajien antauduttava vieläkin tarmokkaammin osaksi yhteiskunnallista debattia terveydestä ja terveydenhuollosta. Erinomaisen esimerkin tästä antoi Helsingin sanomissa (4.1.2018) haasteltu professori Juhani Knuuti, joka totesi haastattelussa seuraavaa: "Avoin keskustelu auttaa minua pois omasta tieteentekijän kuplastani. Opin itsekin koko ajan, ja olen valmis muuttamaan kantaani, jos toinen perustelee asiat paremmin." (6.) Muuttuva mediaympäristö tarjoaa tähän paljon mahdollisuuksia. Esimerkiksi erilaiset sosiaalisen median kanavat mahdollistavat entistä suoremmin kansalaisten, toimittajien ja päättäjien lähestymisen ja vuoropuhelun heidän kanssaan.

Vaikuttamistyöhön ja yhteiskunnalliseen debattiin osallistuminen on asia, josta on helppo puhua, mutta itse toteutus vaatii aikaa, vaivaa ja jatkuvaa hereillä oloa. Onkin todennäköistä ja ymmärrettävää, että yhteiskunnalliseen keskusteluun ja vaikuttamistyöhön osallistuminen herättää ainakin osassa tutkijoista kysymyksiä touhun mielekkyydestä. Nykyisessä toimintaympäristössä tutkijan uran kannalta on nimittäin paljon järkevämpää julkaista mahdollisimman paljon tieteellistä tekstiä ja minimoida kaikki muu puuhastelu. Esa Väliverrosen (2016, s. 63) sanoja mukaillen on kuitenkin syytä todeta, että jos parhaat asiantuntijat eivät osallistu keskusteluun, areenan valtaavat jotkut muut. Sosiaalilääketieteilijöiden - nuorten ja vanhojen - velvollisuus onkin osallistua keskusteluun, jotta sosiaalilääketieteen perusarvoja on mahdollista edistää myös jatkossa. Sopii toivoa, että tulevaisuudessa vaikuttamistyöstä myös palkittaan nykyistä paremmin.

\section{LÄHTEET}

1. Pääministeri Juha Sipilän haastattelu Ylen A-studiossa Sipilä A-studiossa 2.12.2015.

2. "THL varoittaa: Hopeavesi on myrkyllistä - markkinoitu terveystuotteena etenkin ruotsinkielisellä Pohjanmaalla.” Helsingin sanomat 20.11.2017.

3. "Jotkut äidit kieltävät sikiön sykkeen seurannan - pahimmillaan se on aiheuttanut vamman lapselle”. Lännen Media 13.12.2017.

4. "Suomalaismies vaihtoi rasvaisen ruokavalion virallisiin ravitsemussuosituksiin - "30 päivän ihmiskokeen" tulokset yllättävät” MTV 01.03.2016.

5. Esa Väliverronen. 2016. Julkinen tiede. Tampere: Vastapaino.

6. "Lääkäri nousi seisomaan $\mathrm{pH}$-ruokavaliota koskevalla luennolla ja puhui suunsa puhtaaksi - Juhani Knuuti käy sinnikästä taistelua väärän tiedon levittäjiä vastaan". Helsingin sanomat 4.1.2018.

\section{LIINA-KAISA TYNKKYNEN}

FT, yliopistonlehtori, erikoistutkija

Tampereen yliopisto

Yhteiskuntatieteiden tiedekunta

Terveyden ja hyvinvoinnin laitos

Sosiaali- ja terveydenhuollon tutkimus 